\title{
Autor v literárnohistorických súvislostiach
}

\author{
Viera Žemberová (Prešov)
}

\begin{abstract}
Abstrakt
Poetika prozaického textu $v$ slovenskej literatúre od prelomu štyridsiatych a pätdesiatych rokov 20. storočia odráža v literárnohistorických súvislostiach viacero jednotlivostí. Tie sa postupne napájali na výmenu spoločenských a politických reálií, reagovali na reminiscencie doznievajúceho literárneho života prvej polovice 20. storočia a na štatút autora v medzivojnovej literatúre, na formovanie povojnového konceptu a deklarovaného programu novej, modernej slovenskej literatúry, na autorskú aj literárnovednú generačnú výmenu, na selektovanie dominantnej látky a tematiky popri prozaickej projekcii indivídua v próze debutujúcich autorov na konci pät'desiatych rokov. $\vee$ názorovo zložitých pohyboch a diferencujúcich sa estetických a poetologických procesoch treba spomenút' genologické pohyby a nimi iniciované morfologické, estetické a noetické ambície debutantov. V zložitom kultúrno-spoločenskom období sa mení postavenie, rola, závažnost' aj spoločenská dominancia spisovatela, ktorý po skončení druhej svetovej vojny stál pri prameni všetkého „nového“, čo malo posunút slovenskú literatúru do európskeho priestoru.
\end{abstract}

\section{Kl'účové slová}

kultúrna politika; cenzúra; autor; text; žáner; téma; funkcia textu

\section{Abstract \\ The Author in Literary Historical Context}

At the turn of the 1940s and the 1950s poetics of a prosaic text in Slovak literature reflected several individual items in a literary historical context. They were gradually connected to the changes in social and political realities, the reminiscences of a fading literary life of the first half of the 20th century and the status of the author in the inter-war literature, the post-war concept formation and the declared program of new modern Slovak literature, a generational exchange comprising authors and literary history, the selection of the dominant themes in addition to the prosaic projection of an individual in the prose by the debutants at the end of the 1950s. Among the complex changes in opinions and differentiating aesthetic and poetological processes it is necessary to mention the genealogical movements and morphological, aesthetic and noetic ambitions of the debutants initiated by them. In the difficult cultural and social period, the status, role, importance and social dominance of a writer undergo substantial changes. After the Second World War, it is the writer who was the source of all the "new" which should have moved the Slovak literature to Europe.

\section{Keywords}

cultural policy; censorship; genre; author; text; theme; text function 
Spoločenské vedy si svoje obsahy, istoty a hodnoty spravidla odvijajú, alebo porovnávajú ich širšiu platnost̉ tým, ako rozvijajú svoje časom a jeho obsahom utvárané podložia prostredníctvom udržiavanej či obnovovanej tradície v kultúre a umení. Premyslené zbližovanie vedy a umenia pri ich vnútornej členitosti aj početnosti má svoje jedinečné poslanie pri prelomových či zlomových dejoch. Na tie reagujú spravidla všetky zložky spoločenského organizmu sebe vlastným a zdôvodneným spôsobom. Za výsledok akcie a reakcie na ňu sa očakáva vertikálne doriešenie tých ruptúr, ktoré vyvolávajú neprehliadnutelné podnety na premenu a zmenu.

Historiografia, politológia, umenoveda a literárna veda preberajú poslanie, aké prináša ich napojenost̉ a prepojenost od začiatku po koniec spoločenského problému a jeho výrazové prenikanie do umenia v časových, dejových, priestorových, hodnotových, ale predovšetkým v konkrétnych personálnych a umeleckých problémoch, čakajúcich na objasnenie, vysvetlenie, doriešenie toho, čo zatažilo spoločnost', ak v ničom inom, tak v súlade s hodnotou a hodnoteniami autorskej entity, generačnej či konkrétnej autorovej tvorby a jej významu pre - ak už nie autentickú minulosṫ - určite pre spoločnú budúcnosṫ.

Literárna história má štruktúrované portfólio vo svojom materiálovom podloží, čím poskytuje poučené náhlady aj do personálnych dejín tých spisovatelov, ktorí sa vo svojej dobe stali, eufemisticky zachytené, bielym miestom v spoločnosti, na ktoré sa nazerá ako na vyhnanstvo z umeleckého života, vnútorný (tvorivý) exil, na emigráciu. Prímerov na jav biele miesto a na dôsledky v ňom obsiahnuté sa využíva viacero, ale podstata zneprítomnenia umelca a jeho tvorby v spoločenskej realite a v dobovom umení sa svojou podstatou nemení. ${ }^{1}$ Ak platí gnóma, raz sa všetko skončí, tak hladat odpoved' na to, ako dlho bude trvat a či vôbec sa ukončí trvanie a žitie tohto stavu, nemalo svoj hraničný kameň vymedzený.

V moderných dejinách slovenskej literatúry v minulom storočí uchovala literárna história viacero udalostí, ktoré so sebou niesli vlny nových a dalších mien literátov v role svojbytných komponentov včlenených do dobových bielych miest či inak nonkonformných tvorcov voči dobovej kultúrnej praxi, spravidla ako reakciu na strety uskutočnené na podnet neliterárnej skutočnosti a časti spisovatelskej pospolitosti.

\section{Tak, Novomeský, mluvte o své zločinecké činnosti²}

Osud Ladislava Novomeského má svoje osvedčené učebnicové výklady, no dostupné sú aj dôkladne spracované spoločensko-politické podložia spôsobov presadzovania politickej moci po skončení druhej svetovej vojny a jeho osobná účast na organizovaní povojnového (nového) spoločenského systému v spoločnom štáte. Dobové reálie, konkrétni politickí aj spoločenskí činovníci pri moci a dostupné aj dovtedy nezískané fakty prináša beletrizujú-

1 ŽEMBEROVÁ, Viera: Tematizovanie spoločenskej skutočnosti v prozaickom texte (autor, text, ideológia, spoločnost). Moravia 4-2005. Olomouc: Univerzita Palackého, 2005, s. 203 - 210.

2 DRUG, Štefan: Väzeň vlastných súdruhov. $Z$ väzenských rokov básnika Novomeského. Košice - Fintice: FACE Fórum alternatívnej kultúry a vzdelávania, 2015, s. 16. 
ci vklad Štefana Druga Väzeñ vlastných súdruhov. Z väzenských rokov básnika Novomeského ${ }^{3}$ do toho, čo podstúpil novinár, básnik a politik Laco Novomeský v rokoch 1951 - 1954 a čo si žiada aj po rokoch poučenú korektúru pri objasňovaní a zjednodušovaní javu buržoázny nacionalizmus a schematizmus v slovenskej spoločnosti a ňou podporenej kultúry.

Beletrizované rozprávanie ako žáner si nárokuje zo stratégie autora textu (z druhej ruky) dôveru voči materiálu, s ktorým pracuje, ked’že Štefan Drug bol literárny historik, ktorý podstatnú čast’ svojej prítomnosti v literárnej vede spojil s davistami a osobnostou Laca Novomeského. Beletrizované rozprávanie z verifikovatel'ných materiálov a tie dnes patria predovšetkým do dejín politológie a politiky, do historiografie povojnového Československa, vytvára dokumentmi podporený spoločenský a dejinný kontext v sprostredkovanom rozprávaní, v alúziách na vnútorný monológ a na komentár zo širších súvislostí, ktorý prenechal Štefan Drug postave Laca Novomeského. I takto a týmto kompozičným postupom posilňuje nielen stratégiu autora (alter ego), ale dotvára a stupňuje jeho osobnú skúsenost a mravnú hodnotu precíznym aktualizovaním každej, podla mena či funkcie známej persony a reáliami doplnenej udalosti, ktorú zapojí do rekonštrukcie tragickej mnohoročnej udalosti v živote Novomeského: „Utorok 6. februára 1951, ako každé ráno, ide pešo do Slovenskej akadémie vied a umeni na Štúrovej ulici. V pasáži pod kaviarňou Luxor si chce kúpit' cigarety. Nestihne vojst' do trafiky, odskakuje pred cúvajúcim dodávkovým autom. Vyskočia z neho dvaja civili, vykrútia mu ruky za chrbát, zacvaknú putá, sáču ho na zadné sedadlo, zaväzujú mu handrou oči a kážu mlčat'. Čo by aj hovoril? Len si pomyslí: Už je to tu... Minulý týždeň u Clementisovcov nikto nedvihal. Od nedele sa nedovolal k Husákovi. Pochopil, že je rad na ňom. "4 Štefan Drug na Novomeského osude, na jeho skúsenosti s právnym systémom povojnového štátu sa dozvie i toto: „Vy nejste člověk, ale bandita, na vás se trestni zákon nevztahuje! Zradili jste dělnickou tř́du, spojili jste se s buržoazii, aby jste svrhli lidovou demokracii a obnovili u nás kapitalistické žrizeni. “5

Zatknutím Novomeského a jeho umiestnením do väzby v Justičnom paláci v Bratislave sa autor beletrizovaného rozprávania podujal v dvoch líniách sledovat osobnost̉ Laca Novomeského medzi jeho politickými partnermi, ktorí ho na posilnenie svojho politického postu obetovali (Klement Gottwald, Viliam Široký, Karol Bacílek a d’alší). Táto línia má precízne rekonštrukčne vybudovanú a argumentačne takmer heslovite spracovanú legendu, ale pri prienikoch do vnútorných komentárov Novomeského nie raz torzovitú (subjektom reflexívne zvnútorňovanú) kompozíciu, čím silnie psychologický zámer autora, aby si čitatel’ aj dodatočne voči dejinám uvedomil, s akou politickou realitou a mocenskou zvôlou sa stretal a nedokázal im účinne vzdorovat ani skúsený Novomeský. Druhá línia priamočiaro a detailne, bez emócií a pátosu zachytáva pôsobenie rafinovanej mocenskej krutosti, cynickej neludskosti a ponižovanie až po výsledok prepracovanej „hry“ vyšetrovatelov, po zlomenie osobnosti Laca Novomeského a jeho sebazničujúce výpovede v súdnom procese: „Pokúšal sa vyšetrovatel’om vysvetlit', že po príchode delegácie

3 DRUG, Štefan: Väzeň vlastných súdruhov. Z väzenských rokov básnika Novomeského. Košice - Fintice: FACE Fórum alternatívnej kultúry a vzdelávania, 2015.

4 Tamže, s. 8 - 9 .

5 Tamže, s. 16. 
SNR z Londýna do Moskvy sa vari denne rozprával najmä s Gottwaldom a Kopeckým o otázkach budúceho postavenia Slovenska v obnovenej republike."6

Vedla politika, pretože látkou a tematikou defiluje Drugovým beletrizovaným rozprávaním predovšetkým táto čast’ Novomeského aktívnej prítomnosti v povojnovej slovenskej politike, prežíva vo väzbe aj básnik Novomeský. Básnikovi po dlhom čase, ked' vyšetrovatelia uznali, že sa podla potrieb pripravovaného súdneho procesu mentálne ocitol v nimi inštalovanej politickej a mocenskej hre svojich bývalých kolegov a priatel'ov v politike, umožnili mu čítat: „Vie, že sa zbytočne vzrušuje, ved’ môže byt’ rád, že mu dali aspoň takéto čítanie."7 Skutočnou zmenou a odmenou za poddanie sa moci vyšetrovatelov bol papier a ceruzka: „Opät’ píse poému. Nazýva ju symbolicky Ján, lebo toto meno je na Slovensku, najmä na dedine, najbežnejšie. Na Jánovi chcel ukázat’ rapsodickú cestu Slovenska od dediny $k$ mestu, od rol'nika $k$ proletariátu, od dedinskej zadubenosti k revolučnej uvedomelosti na tvrdej nákove slovenských skúšok a skúseností pred prvou svetovou vojnou, počas nej i v neskorších rokoch a udalostiach. "

Laco Novomeský prežil spôsoby a metódy svojich väznitelov, aby v šesṫdesiatych rokoch (1963 - 1968), po návrate do občianskeho života a po politickej rehabilitácii, ked' vyšla poéma Vila Tereza a dve d’alšie básnické knihy, znova zažil poučenejší, ale s rovnakým zámerom rafinované politické zneužívanie svojho mena a občianskej povesti: „Nesúhlasil ani s nastupujúcou normalizáciou a protestoval proti nej tak bytostne, že v polovici roku 1970 t’ažko ochorel a už sa nevyliečil. "9

Napriek plynúcemu času medzi politikou a umením, medzi dôverou a jej zneužitím, medzi mocou a jej obetou ostávajú tie isté úzke chodníčky vydláždené stratou seba samého.

\section{Chaja Wolfowitzová, Siahni si, ako ma to bolíio}

Prozaička Hela Volanská ${ }^{11}$ sa pripomína ako autorka vojnových a povstaleckých próz, ${ }^{11}$ reportáží zo zahraničia, románov z lekárskeho prostredia a v samizdate vydanej práce Concordia (1987). Recepcia Volanskej ${ }^{12}$ prozaického diela patrí medzi osihotené súkromné čitatel'ské iniciatívy, čo znamená i to, že jej prózu bude tažšie nájst̉ ako výstup genologicky či esteticky interpretovanej alebo žánrovo, či poetologicky analyzovanej umeleckej literatúry vo vývinovom priereze od polovice minulého storočia.

Prvé vydanie autobiografického románu Ako na cudzej svadbe ${ }^{13}$ patrí do konca osemdesiatych rokov, ${ }^{14}$ pre literárnu históriu do záverečnej časti, či doznievania druhej epickej

6 Tamže, s. 31.

7 Tamže, s. 41.

8 Tamže, s. 25 - 26.

9 Tamže, s. 63.

10 VOLANSKÁ, Hela: Siahni, ako ma to bolí. Bratislava: Slovenský spisovatel', 1970.

11 Hela Volanská vydala práce Stretnutie v lesoch (1948), Tajomstvo (1950), Kvet paprade (1961), Planéty (1965), Domino (1966), Jed (1957), Siahni si, ako ma to boli (1970).

12 Hela Volanská, občianskym priezviskom Chaja Wolfowitzová (1912 - 1996).

13 VOLANSKÁ, Hela: Ako na cudzej svadbe - prvé vydanie signuje rok 1987.

14 Volanská text ukončila a pripravila na vydanie v roku 1989. 
syntézy, do oslabenia tematického historizmu v slovenskej románovej tvorbe desaṫročia a do útlmu línie memoárovej a autobiografickej tvorby autorov staršej literárnej generácie, ktorá výrazne zasiahla práve svojou koncíznostou výpovede aj kultúrnou pamätou a hodnotami do aktuálneho, vnútorne sa diferencujúceho literárneho života od šesṫdesiatych rokov, ${ }^{15}$ aby generačná spomienková empíria v literatúre na konci storočia postupne utíchla jednak prirodzene svojím vydavatel'ským naplnením sa, ale viac pod tlakom vnútroliterárnych procesov v pozjazdových ${ }^{16}$ sedemdesiatych rokoch.

Personalizovaná látka, téma, fabula, narátorka, ale aj reč literárnej výpovede zachytávajú z jediného bodu, tým sa stala intímna a občianska pamät personalizovanej rozprávačky, udalosti odohrávajúce sa v strednej Európe od tridsiatych rokov do povojnových desatročí, v ktorých sa l'udský, občiansky i profesijný život postavy spájal s tým, čo historické, politické, ekonomické, konfesijné a etnické udalosti pretínajúce sa vo vojnovej dráme niesli so sebou aj vtedy, ked' sa literárne tematizovaná vojnová udalost’ stávala rozpomienkou na nie tak nedávne deje a na ich presah do životov tých, čo ju prešli a prežili na bojiskách, v horách, koncentrákoch a nemocniciach.

Napokon literárny historik Vladimír Petrík o tejto línii Volanskej textu uvažuje takto: „Próza Ako na cudzej svadbe má teda vecnú rovinu, ktorú možno prikladat' ku skutočnosti a ktorá súvisi bezprostredne aj s autorkinou biografiou. Je v nej však aj poézia spomienok tam, kde sa vrátila do detských rokov, a vtedy pracuje s typizačnými prvkami. Rodinné prostredie a širši spoločenský rámec, v ktorom rodina žije, je vierohodnou výpoved'ou o živote židovskej komunity v Pol’sku a o vzt’ahu príslušnikov väčsinovej spoločnosti k nej. To znamená, že próza splña aj žánrovú charakteristiku autobiografického románu. Zároveň je však svedectvom. Vydáva svedectvo o autorke a o dobe. Každé svedectvo je subjektívne a platí to nepochybne aj v tomto prípade, kde sa pravda umenia tesne stýka s pravdou života. Možno povedat', že sila suverénneho umenia tak znásobuje pravdu života. "17 Literárny kritik v rubrike Literárium pod titulom Peripetie života samizdatovej autorky napísal popri inom: Volanskú „Už ako lekárku žilinskej nemocnice [...] sleduje bezpečnost', dostane sa do väzenia a neskôr do tábora v Novákoch a odtial' utečie do Slovenského národného povstania, v ktorom sa uplatni jej lekárska skúsenost'. Tu sa už stretáva so známymi postavami a ich plnými menami ${ }^{18}$ [...] Volanská toto obdobie opisuje velmi hodnoverne a jej štýl pôsobi autenticky. [...] Pobyt na Slovensku je opisaný drsnejším štýlom až dokumentárne. Práve z tohto hladiska by sa mali v určitých pasážach uvádzat' plné mená aktérov. "19

Volanskej nepatetická, nemoralizujúca, iba rekonštruujúca rozpomienka na dejiny vojnovej a povojnovej Európy precúdené prostredníctvom jediného ludského života patrí medzi „dokumenty“ hrôzy, ktorým sa humánne zmýšlanie o človeku, spoločenstve,

15 Memoárové prózy Jána Hrušovského, Mila Urbana, Andreja Plávku, Štefana Žáryho, Jána Smreka, Pavla Bunčáka, Hany Zelinovej a d'alších.

16 II. zjazd slovenských spisovatelov v roku 1972, prijatý bol dokument Poučenie z krízového vývoja v strane a spoločnosti. Kultúre a umeniu sa venujú záverečné časti, v nich je požiadavka na látku a protagonistu zo súčasnosti.

17 PETRÍK, Vladimír: Sila umenia a pravda života. In: VOLANSKÁ, Hela: Ako na cudzej svadbe. Bratislava: Vydavatelstvo Marenčin PT, 2009, s. 245 - 246.

18 Volanská uvádza autentické priezviska straníckych funkcionárov Ďuriš, Široký, Reimann, Zupka.

19 BŽOCH, Jozef: Peripetie života samizdatovej autorky. Sme, 12. 3. 2010, s. 18. 
spoločnosti a o „pošliapaných pojmoch Spravodlivost'. Pravda. Svedomie“20 nechce uverit, že sa v civilizovanej Európe 20. storočia vôbec mohli stat', navyše v slovanskom svete, na Slovensku, v Pol’sku a v Čechách. A predsa sa stali, v pätdesiatych rokoch zasiahli tragicky do života, profesie, vztahov aj do nazerania na zmysel života, na rodinu a na ideály povojnového sveta spisovatel'ky a lekárky Hely Volanskej, stali sa aj jej rovesníčke, spisovatel'ke Hane Ponickej ${ }^{21}$ v sedemdesiatych rokoch. ${ }^{22}$

Intenzita prežitého a tlak autentického poznania ako následok i dôsledok osobnej pamäti z dramatických a existenciálne pointovaných vojnových skúseností sú v próze Ako na cudzej svadbe v takej presile, že d’alšie tvorivé i občianske „osudy“, ktoré Helu Volanskú stretli v normalizačných rokoch, oslabili jej literárny záujem o vyrovnanie sa s týmto úsekom svojej biografie: „V rokoch normalizácie nesmela publikovat’ [...]. Jej situácia sa znova skomplikovala na „vstupe vojsk“ a po zákaze publikovania. O tomto čase previerok a vyhadzovania z práce však hovori málo. "23

Hela Volanská svoju tému vytažila z detstva v Pol’sku, zo štúdií v Bratislave, z vojnových a povstaleckých udalostí na Slovensku, ktoré ju v povojnových rokoch vysunuli na exponované miesto v spoločnosti, aby podstatnú čast' svojho neliterárneho osudu v pätdesiatych rokoch vyrozprávala spôsobom, ktorý narátorku presúva z fikcie umeleckej prózy medzi historickým dokumentom zachytené a spracované reálie a medzi verifikovatel’né neliterárne postavy.

\section{... znova sa všetko opakuje? ${ }^{24}$}

Hana Ponická svoju skúsenost̉ zachytila v súlade s postupmi literatúry faktu a verifikácia sa tak stala primárnym postupom pri rozprávaní a rozvíjaní látky aj tematiky v Lukavických zápiskoch, a to preto, lebo zachytila spoločenské a osobné normalizačné roky, praktiky a ich dôsledky. V literárnej histórii Ponickej text „zápiskov“ patrí do dejín slovenskej samizdatovej tvorby 20. storočia. ${ }^{25}$

Vladimír Petrík vydavatel'ské peripetie a oneskorené vydanie Lukavických zápiskov na Slovensku objasňuje takto: „Vari preto, lebo v tejto publikácii sa Ponická dost’ nešetrne dotýka významných (i menej významných autorov), ktori v obdobi normalizácie menili názory a občas aj charaktery [...]. Lukavické zápisky sa začínajú rokom 1977, teda rokom, v ktorom vznikla Charta 77. Tá akcelerovala vývin a pôsobila v oblasti kultúry i politiky ako bomba. S ňou sú spojené

20 VOLANSKÁ, Hela: Ako na cudzej svadbe. Op. cit., s 239.

21 Hana Ponická (1922 - 2007).

22 PONICKÁ, Hana: Lukavické zápisky. Prešov: Vydavatel'stvo Michala Vaška, 2004.

23 PETRÍK, Vladimír: Sila umenia a pravda života. In: VOLANSKÁ, Hela: Ako na cudzej svadbe. Bratislava: Vydavatelstvo Marenčin PT, 2009, s. 245 - 246.

24 Vyňaté z výroku historika Vrbenského z práce PONICKÁ, Hana: Lukavické zápisky. Brno: Atlantis, 1992, s. 376.

25 PETRÍK, Vladimír: Odkryté praktiky znormalizovanej spisovatelskej organizácie (Sme, 18. 11. 2004: „Po „petlicovom“ vydaní Ludvíka Vaculíka vyšli knižne roku 1989 u Josefa Škvoreckého a roku 1992 v brnianskom vydavatelstve Atlantis“, v roku 2004 vo Vydavatel'stve Michala Vaška v Prešove). 
perzekúcie spisovatel'ov a kultúrnych pracovnikov, súdy, zatvárania, zákazy publikovat', výpovede zo zamestnania atd’. Väčsina toho sa odohrala v Prahe, ale stojaté vody sa pohli aj na Slovensku - charta odkryla skutočnú tvár režimu, ktorý sice podpisal „helsinské dohovory“, ale nikdy nemienil ich ustanovenia plnit.' [...] Nie je to len o faktoch jedného osudu, akých bolo napokon vel'a, autorka tu rozvija vlastnú predstavu o tom, ako by mala vyzerat' kultúra $v$ danom spoločenskom rámci, zamýšla sa nad všeličím, spomina si na významných európskych autorov, ktorých poznala [...], nechýbajú prírodné reflexie, ktoré dvihajú vecný text zápiskov na úroveň beletrie. "26

Dva odlišné životy, dve rozličné spisovatel'ské dielne, ale blízka skúsenost’ so spoločnostou, ktorá si prestala vážit hlas umenia a jej tvorcu preto, lebo dôverovala iba svojej reálnej moci.

\section{Vyhnanstvo upevňuje vieru v návrat ${ }^{27}$}

V roku 1951 sa konalo stretnutie spisovatelov komunistov s Júliusom Šefránkom, zastupujúcim aparát kultúrnej politiky. V jeho referáte sa medzi tými, ktorí sa odklonili od predstavy obnovenia socialistického realizmu a smerovania povojnovej slovenskej literatúry, ocitol aj Vladimír Mináč popri Dominikovi Tatarkovi, Alexandrovi Matuškovi alebo Michalovi Chorváthovi. ${ }^{28}$ Dominik Tatarka a Vladimír Mináč v krátkej próze stále častejšie reagovali na obnovované ludské a funkcionárske neduhy v spoločnosti a tieto ich postoje voči budovanej povojnovej spoločenskej realite a jej praxi si nezískali oficiálnu podporu. ${ }^{29}$

Následkom stupňujúceho sa zložitého vztahu medzi autorom a riadenou kultúrnou praxou patria do pozornosti literárnej histórie prózy Vladimíra Mináča, ktoré v čase svojho vzniku cenzúra neodporučila zverejnit. ${ }^{30}$ Mináčove „zakázané prózy“ - žánrovo obsiahnu črtu a poviedku - pôvodne tvorili obsah do tlače pripravenej publikácie $Z$ nedávnych čias. Dôraznejšie ako spätné reflektovanie toho, čo rukopis postretlo, je citovat z dokumentu „Správy tlačového dozoru, teda hlavného orgánu komunistickej cenzúry“: „Vydavatel'stvo Slovenský spisovatel'v rukopisoch predložilo ku kontrole knihu črt a poviedok Vl. Mináča Z nedávnych čias. Pretože $k$ obsahu knihy boli vážne pripomienky, nedali sme súhlas k tlači. Kniha obsahovala 6 črt a poviedok, a to: Svedomie, Strach, Papula 1, Nedorozumenie, Zápisky cynika, Ako ma na recepcii pokúšal diabol. Dej poviedok sa odohráva v rôznych obdobiach nášho života od roku 1944 až podnes. Autor našu nedávnu minulost' hodnotil ako obdobie teroru. Funkcionárov opisoval ako bezcharakterných a bezzásadových l'udi, čo vyústovalo v poslednej

26 PETRÍK, Vladimír: Odkryté praktiky znormalizovanej spisovatelskej organizácie. Sme, 18. 11. 2004.

27 MINÁČ, Vladimír - PODRADSKÁ, Dana: Paradiso. Bratislava: Vydavatelstvo Spolku slovenských spisovatelov, 1998, s. 59.

28 MARUŠIAK, Juraj: Slovenská literatúra a moc v druhej polovici pätdesiatych rokov. Brno: Prius, 2001.

29 MATEJOVIČ, Pavel: Vladimír Mináč a podoby literárneho diskurzu druhej polovice 20. storočia. Bratislava: Kalligram, 2014; čast̉ D. Tatarka a V. Mináč, s. 274 - 284.

30 MINÁČ, Vladimír: Zakázané prózy. Bratislava: LIC, 2015. 
poviedke Ako ma na recepcii pokúšal diabol, ktorá na zásah PV - Správy tlačového dozoru bola už predtým vypustená z Kultúrneho života."31

Čas l’udí aj kníh plynie, ale príbehy a skúsenosti získané z nich sa môžu paradoxne aj približovat', ako Mináčov postoj voči mladým autorom o dve desat'ročia neskôr.

\section{... dost' bolo nárekov, odteraz Ti budem písat' len veselo}

Tento odkaz začína list Drahej E., ktorý jej adresuje Jaroslava Blažková v próze Happyendy. ${ }^{32}$ Kritik Jozef Bžoch ${ }^{33}$ uvádza do povedomia čitatela svojej recenzie podstatnou kontextovou súvislostou vo vztahu k literárnohistorickému reflektovaniu tvorby Jaroslavy Blažkovej, podla kritikovej informácie odišla v roku 1969 do kanadskej emigrácie s rodinou, hoci v slovenskom literárnom živote šesṫdesiatych rokov bola známa a vyhladávaná autorka; život za morom označil za jej dobrovolné vyhnanstvo. Do vydania Happyendov vpísala Jana Cviková Ked’ žena píse žene $e^{34}$ i to, že „Z Kanady ju nelákala formálna rehabilitácia, mala jediné prianie: oživenie svojich kníh", čo jej vydavatel'stvá Aspekt a Q 111 plnia dodnes.

Listová skladačka všeličoho a o všeličom ludskom v Happyendoch pracuje s paradoxom a kauzalitou svojej témy, do ktorej sa dokáže včlenit rozprávaním ktorákol'vek sekvencia jej života po emigrácii. Jednosmerne adresované, nedatované, nelokalizované, nepersonalizované osobné listy inej žene (Drahá E.), zachytávajú v úlomkoch žitého osobný život Jaroslavy Blažkovej a jej chorého manžela. I teraz obstojí, že si nestažuje, nie je sentimentálna, v spodnom prúde svojich slov neukrýva odkazy do minulosti, nežiada, iba realisticky a reálne prijíma to, čo jej a rodine nadelil čas.

Jaroslava Blažková seba umiestňuje do epicentra osobnej a rodinnej križovatky, v ktorej sa stretajú život a smrt, ale aj rozpomienky a vyčkávanie. Ako „momentálna Kajúcnica“ ukončuje list adresovaný drahej E. takto: „P. S.: Uvedomila si si, že smrtka je v angličtine mužského rodu? Beda nám feministkám. "35

Odchod do emigrácie či do vyhnanstva z vlastnej vôle povýšila autorka na povinnost' aktívneho života s jeho zákrutami a prispôsobovaním sa cudziemu, čím odmietla myšlienku vytrvalého vyčkávania na príležitost', čo bude, ked' sa azda raz príčiny na jej odchod zmenia. Blažkovej porozumenie životu znamená rešpekt voči času, ktorý plynie a dôvera v správnost’ pôvodného rodinného rozhodnutia: ona ostáva v novom kanadskom domove, ale jej knihy sa vrátili medzi slovenských čitatel’ov. Vie, že je to tak správne a voči realite času jedine možné.

31 Prevzaté z časti MATEJOVIČ, Pavel: Mináč ako záhadný autor? In: MINÁČ, Vladimír: Zakázané prózy. Op. cit., s. 9.

32 BLAŽKOVÁ, Jaroslava: Happyendy. Bratislava: Aspekt, 2005.

33 BŽOCH, Jozef: Happyendy napisané v najtažšom životnom obdobi. Sme, 24. 11. 2005.

34 BLAŽKOVÁ, Jaroslava: Happyendy. Bratislava: Aspekt, 2005, s. 193 - 198.

35 Tamže, s. 125. 


\section{Generácia, ktorá bola pri tom}

Na počiatku boli absolventi filologických štúdií, neskôr kolegovia v printových a d’alších médiách rozličného druhu, aby sa napokon na prelome dvoch desatročí stretli v periodikách s krátkym životom v dobovom literárnom živote a kultúre, časopisoch Krok a sčasti aj Realita.

Iva Kadlečíková v publikácii spomienok, faktov, návratov, overovania si toho, čo bolo, ktorú nazvala Č́tanie myslenia ${ }^{36}$ sa sústredila na rovesníkov, ${ }^{37}$ teda na tých, ktorí odišli z bratislavských univerzitných štúdií do Košíc, ktoré im pripravilo budúce pôsobiská vo Východoslovenskom vydavatel'stve, v rozhlase, v televíznom štúdiu - a oni popri tom prvotnom obnovovali literárny život v meste a regióne prostredníctvom periodika Krok ${ }^{38}$ : „Krok bol prvým konkrétnym krokom na našej spoločnej ceste, pokúsil sa aktivizovat' všetky schopné sily z viacerých oblasti kultúry na celom východnom Slovensku, aby sa stali integrálnou a plnokrvnou súčastou národnej kultúry. Žial', v Košiciach aj naším krokom posledným. “39 Kadlečíková má ambíciu vypovedat’ o všetkom ako účastníčka tejto kultúrnej misie: „Krok 66 - zbornik pre literatúru a umenie. Vychádza 4-krát do roka. Vydáva Východoslovenské vydavatel'stvo v Košiciach 1966. Redigujú Ivan Kadlečik a Jozef Mríz. Spolupracuje Albín Bagin. Zodpovedný redaktor Imrich Gofus. Obálka Zoltán Sokolovič. Strán 64. Náklad 3000.“"0

Redakčné a edičné dejiny Krok-u sú však komplikovanejšie nielen tým, že svoj kultúrny životopis spojili s východným Slovenskom šestdesiatych rokov, ale i tým, že zložité spoločenské procesy tohto desatročia pozmenili periodikum, ale aj osobné a profesijné príbehy tých, ktorí sa usilovali slovom preklenút vzdialenost̉ medzi kultúrnymi centrami východu a západu Slovenska. Najskôr takto aj z odstupu desatročí má zmysel vrátit sa $\mathrm{k}$ ankete iniciovanej redakciou o domove a literatúre ${ }^{41} \mathrm{a}$ ich noetickom odraze $\mathrm{v}$ spoločnosti, kultúre, v tvorbe regionálnych tvorcov.

Pointou formálneho zúčtovania s Krok-om sú tieto jej zápisy: „Zalistujme si teda v dvoch knižočkách ručne viazaných, do ktorých sú sústredené pokusy o časopis, kompromisne štyri „zborniky“ Krok 66 a šest’ „zbornikov“, od štvrtého čísla už „časopisov“, Krok 67." Ive Kadlečíkovej záleží predovšetkým na tom, aby sa publikácia Čítanie myslením stala autentickou správou a až potom archívom periodika, doby, ludí a udalostí, ktoré stáli pri jeho vzniku a pri jeho rýchlom zániku.

36 KADLEČÍKOVÁ, Iva: Čítanie myslenia. Ivánka pri Dunaji: F.R.\&G., 2011. 237 s.

37 V auguste 1961 do Košíc sa z Bratislavy po ukončenia štúdií na Univerzite Komenského presídlili Ivan Kadlečík, Albín Bagin, Jozef Mríz, Imrich Gofus, Ol'ga Chrenková, Iva Hadačová. Odbočku Zväzu slovenských spisovaelov v tom čase v Košiciach viedla Marína Čretková Gállová.

$38 \mathrm{~V}$ šesṫdesiatych rokoch 20. storočia založili periodikum Krok, udalosti okolo jeho genézy i zániku Iva Kadlečíková uzatvára vyčerpávajúcou i vševediacou informáciou: „Bola som pri tom všetkom. Od začiatku až po koniec v Košiciach, od začiatku až do konca v Martine. Bola som účastnikom, pomocníkom, spolupracovníkom, pozorovatelom“. In: KADLEČÍKOVÁ, Iva: Čítanie myslenia. Op. cit., s. 8.

39 KADLEČÍKOVÁ, Iva: Čítanie myslenia. Op. cit., s. 8.

40 Tamže, s. 11.

41 Tamže, anketa viazaná na entitu domov a literatúra.

42 Tamže, s. 11. 
K spoločenským okolnostiam zániku sa vrátili Oleg Pastier a Ivan Kadlečík, ked’ na dopytovanie sa, prečo „Východoslovenský časopis Krok nevydržal. Dva ročniky, dva pokusy o trvalejši kultúrny zápis do slovenskej literatúry konca šesṫdesiatych rokov, ked' sa zdalo, že skoro v̌setko je možné. Ale nebolo... Prečo tento viac ako nádejný časopisecký pokus zostal "nedokončený“, odpovedal Ivan Kadlečík podstatnou informáciou, ktorá obnažuje v redakcii „[...] určitú koncepčnú a názorovú divergenciu. So svojou širšou víziou univerzálnejšej a neprovincionálnej kultúry a literatúry som ostal takmer sám, " ${ }^{43}$ hoci na pomoci mu boli príspevkami Albín Bagin, Rudolf Chmel, Ján Štrasser, ale košická činovníčka Zväzu slovenských spisovatelov „bola, zdá sa, dost' nerozhodná“, aby zosumoval nielen príbeh Krok-u, ale aj svoj osobný a rodinný takto: „Rozheganú a rozbabranú situáciu v Košiciach sa po auguste 1968 ešte neúspešne pokúsila zachránit Marina Čeretková Gállová časopisom Realita“ ${ }^{44}$ ale i ten zanechal po sebe iba jedno číslo.

Iva Kadlečíková v pravý čas, život to potvrdil (odišli Albín Bagin, Damián Vizár, Pavol Hrúz, Ivan Kadlečík), povýšila autentické z osobného života na literárnohistorické univerzum. K osobnosti s odstupom od dejov okolo periodík Krok a Matičného čítania sa vyjadril o Ivanovi Kadleč́́kovi ${ }^{45}$ aj Pavlovi Hrúzovi glosátor Ján Štrasser v publikácii Čítam... (2012), aby upozornil na to, že „Písanie ako sebaidentifikácia, súkromná konfrontácia, vyjasňovanie si, kto si a čo si a v akých súvislostiach priestoru a času si “. Spoločne a v odlišných spoločenských dejoch považujú za nenahraditelnú strelku istoty života toho, kto svojím slovom a postojom nasmeruje pozornost̉ súčasníkov a spoločenskej praxe na seba a svoje činy, lebo i tak naznačuje spoločné trasovisko, ktoré si nemožno nevšimnút.

\section{Čriepky literárnej kritiky do mozaiky literárnej histórie}

Podmieňujúci vztah medzi literárnou kritiku a literárnou históriou ostáva pre literárnu vedu iniciačný. Naposledy svoje čriepky do utvárania profilu Vincenta Šikulu v kultúre a literatúre od polovice minulého storočia vložili Veronika Šikulová rozpomienkami Freska $v$ dome $e^{46}$ od čias svojho detstva po čas, ked' jej literárna šłastena spravodlivo určila rozprávačský dar a miesto po tatuškovi. Inak sa k Vincentovi Šikulovi vypravil Vincent Šabík, ktorý si zvolil rolu dokumentárneho rekonštruovania svojho profesijného vztahu k spisovatelovi v súbore kritických textov Čriepky do portrétu Vincenta Šikulu ${ }^{47}$ Súbor „šikuliány“ ani post factum nič nestráca na svojej aktuálnosti a na užitočnosti dotvárat prostredníctvom názorových, generačných, personálnych a koncepčných prepojení medzi jednotlivým a všeobecným, čo sa v tomto Šabíkovom projekte osvedčí, popri inom, pri ustalovaní vertikály okolo polemiky z druhej polovice sedemdesiatych rokov v Sloven-

43 Tamže, s. 94.

44 Tamže, s. 95.

45 ŠTRASSER, Ján: Čitam.... F.R.\&G., 2012; čast' Ivan Kadlečík: Rapsódie a miniatúru. Atlantis, 1992, (1988 - 1992), s. 214 - 215.

46 ŠIKULOVÁ, Veronika: Freska v dome. Bratislava: Literárne informačné centrum, 2014..

47 ŠABÍK, Vincent: Čriepky do portrétu Vincenta Šikulu. Bratislava: Spolok slovenských spisovatelov, 2015. 
ských pohladoch, ktorá sa sústredila na Majstrov [O Šikulovej trilógii zoširoka $i$ naúzko ${ }^{48}$ z roku 1980; Čítanie a chápanie dejín. Hermeneutický princíp „zdola“ 49 z roku 2015; Ján Števček: Vincent Šikula: Majstri (posudok) z roku 1975 ${ }^{50}$.

Literárna história má svoj archív, intímnu pamät', azda aj odlišne motivovaný profesijný vztah k tým, ktorí ju vytvárajú svojím talentom, zmýšlaním a rozhodnutiami. No má aj svoju utajenú alebo iba nepoznanú, ba až miestami nepriznanú človečinu, ktorá si od nástupcov v literárnej vede žiada nielen, aby o minulosti (národnej) literatúry mali povedomie, ale predovšetkým, aby porozumeli tomu, čo prekrýva patina času, čím sa nevytráca naliehavá výzva hladat’ za slovom človeka v jeho tvorivej a osobnostnej jedinečnosti. A to i vtedy, ked’ sa to, čo s ním v učebnici súvisí, javí ako jasné a dostredivé. Literárna veda a jej precizované poznanie napovedá, že opak býva pravdou.

\section{Literatúra}

BLAŽKOVÁ, Jaroslava: Happyendy. Bratislava: Aspekt, 2005.

DRUG, Štefan: Väzeñ vlastných súdruhov. Z väzenských rokov básnika Novomeského. Košice - Fintice: FACE - Fórum alternatívnej kultúry a vzdelávania, 2015.

MATEJOVIČ, Pavel: Vladimír Mináč a podoby literárneho diskurzu druhej polovice 20. storočia. Bratislava: Kalligram, 2014.

MERVART, Jan: Naděje a iluze. Čeští a slovenšti spisovatelév refomním hnutí šedesátych let. Brno: Host, 2010.

MINÁČ, Vladimír: Zakázané prózy. Bratislava: Literárne informačné centrum, 2015.

PAŠTEKOVÁ, Jana (ed.): Poetika a politika umenia a pätdesiate roky. Bratislava: Slovak Academic Pres, 1994.

PERSTICKÁ, Dagmar - PǨEROSTOVÁ, Lea: Dominik Tatarka a ti druzi. Informace o umlčované a zamlčované slovenské literatuře. Brno: Státní vědecká knihovna, 1991.

PONICKÁ, Hana: Lukavické zápisky. Brno: Atlantis, 1992.

ŠABÍK, Vincent: Čriepky do portrétu Vincenta Šikulu. Bratislava: Spolok slovenských spisovatelov, 2015.

ŠIKULOVÁ, Veronika: Freska v dome. Bratislava: Literárne informačné centrum, 2014.

\section{prof. PhDr. Viera Žemberová, CSc.}

Inštitút slovakistiky a mediálnych štúdií

Filozofická fakulta, Prešovská univerzita v Prešove

UI. 17. novembra č. 1, 08001 Prešov, Slovensko

viera.zemberova@ff.unipo.sk

48 Tamže, s. 73 - 94.

49 Tamže, s. 211 - 213. Pozornost̉ treba venovat aj Šabíkovým parciálnym postojom, ktoré venoval jednotlivým častiam trilógie v II. časti publikácie, s. 31 - 94.

50 Tamže, s. $215-218$. 
